\title{
Exploring the extension of unified theory of acceptance and use of technology, UTAUT2, factors effect on perceived usefulness and ease of use on mobile commerce in Egypt
}

\author{
Noha Bendary \\ Faculty of BAEPS, The British University in Egypt, Cairo Egypt \\ Ibrahim Al-Sahouly \\ Faculty of Management \\ October University for Modern Arts and Science, Cairo, Egypt
}

\begin{abstract}
Keywords
Convenience, Social influence, Hedonic motivations, perceived usefulness, ease of use
\end{abstract}

\begin{abstract}
This paper aims to study the factors that enhance perception of mobile commerce users to promote such form of shopping in Egypt. Researchers explored the factors affecting users of Mobile communication and electronic shopping by identifying all factors considered in technology users' behaviour theories. Researchers conducted an exploratory research, to examine the most relevant factors for mobile commerce adoption, also, tested the reliable and valid measures extracted, for considering its effect on the user's perception of its usefulness and ease of use. Three factors were considered of main importance: social influence, convenience and hedonic motivations. Researchers tested those factors and they all affected User's perception, further They affected each other. Thus, researchers concluded that, in Mobile commerce, Social influence were fully mediated with hedonic motivation and convenience. As of Convenience, it tends to be the most affecting for perceptions of consumers usefulness and ease of use also, it has a strong mediation effect between social influence and mobile commerce user's perceptions.
\end{abstract}

Corresponding author: Noha Bendary

Email addresses for corresponding author: noha.bendary@gmail.com

First submission received: 5 th June 2017

Revised submission received: 30th July 2017

Accepted: 10th September 2017

\section{Introduction}

Worldwide, expansion of electronic commerce and the surge of mobile commerce developed new opportunities and markets for businesses. According to global Retail survey (PWC, 2015), 47\% of global consumers used mobile devices to make purchases during 2014 compared to $30 \%$ two years earlier, which implies a rapid growth in mobile device usage as one of the means of conducting online shopping. Moreover, $62 \%$ of global mobile device users compared to $75 \%$ in the Middle East believe that purchases are more likely through social media. In the Middle East, Egypt has the largest population for online buyers, $15.2 \%$. However, due to the low purchasing power and other challenges such as security concerns for payments, the United Arab Emirates and Kuwait have more online buyers for e-commerce (Daily News, May 2015). In the UAE, $46 \%$ of total internet users are online consumers. On the other hand, in Egypt, which has the highest number of internet users, $55 \%$, only $8 \%$ of total internet users are online consumers. Moreover, mobile internet users constitute only $22 \%$ of mobile subscribers who are almost 95 million. (Payfort, April 2015). Consequently, there is a huge potential in this market for M-commerce, however; there is still limited usage of such technology which possess lots of questions for the reasons underlying.

To understand the term mobile commerce (m-commerce), the term split into "Mobile" and "commerce". Mobile means "Anywhere and anytime access". This access takes place through mobile communications networks, which facilitates this access regardless of geographic location (Hohenbery and Rufera, 2004). M-Commerce is defined as "buying and selling of goods and services, using wireless handheld devices such as mobile telephones or personal data assistants" (UNCTAD, 2002), or conducting 
transactions using communication networks (Muller-veerse, 2000). A mobile device is a wireless connection, however, not all wireless devices are mobile applications (Ancher and Dincau, 2002). Mobile commerce is as part of the electronic commerce evolution and many theories governing e-commerce can be explored for M-commerce to explain consumer behavior for such technology. Theories such as TAM (Technology Acceptance Model), TPB (Theory of planned Behavior), TAM2 (the extension of TAM), UTAUT (Unified Theory of Acceptance and usage of Technology) and UTAUT2 (The Extension of the Unified Theory of Acceptance and usage of Technology) are known theories for explaining consumer behavior in using technologies and electronic commerce. This research aims to study factors hypothesized in these theories and their effect on Mobile commerce in Egypt.

\section{Theoretical frame work}

There are an abundance of theories and models that attempt to explain consumer behavior in using technologies and electronic commerce, as TAM, TPB and TAM2. The technology theories originated from the theory of reasoned actions (TRA). This Theory considers the effect of experience, person's demographics characteristics and personality traits on behavioral performance. Also, Perceived control was added to such theory, which led to the development of the theory of planned behavior (Ajzen, 1991; Ajzen, 1988). Ajzen (1988) explained perceived control as the level of difficulty of performing a behavior, and, hypothesized a direct relationship between perceived control and buying intentions (Ajzen, 2002). Thus, the behavioral buying intentions were considered as representative of consumer behavioral performance as of TPB. Behavioral intention is defined as the willingness and motivation to commit effort or time to a certain behavior (Courneya et al., 1999). Attitudes, subjective norms \& perceived behavior control were added to TPB. Later, The TAM was developed for accessing user behaviour of information system technologies. It was an antecedent of TRA and TPB as it considered both buying intentions and attitudes. Its goal was to define the determinants of computing acceptance and its technology, through a theoretical based theory (Davis et al., 1995). The TAM emphasizes a person's behavior towards technology by his attitudes and beliefs toward this technology. The perceived usefulness and ease of use were the main determinants of attitudes. The TAM model lacks normative constructs, such as the facilitating conditions component of perceived control, and affective measures of habit. The TAM model was extended, by Vankaetesh and Davis (2000), by incorporating subjective norms, image, job relevance, output quality \& result demonstrability.

Proceeding on theories of behaviour prediction to Technology, The Unified Theory of Acceptance and Use of Technology (UTAUT) developed as an extension for TAM and TAM2 models (Venkatesh et al, 2003). In this model, there are four key constructs that predicted behavioural intentions to use technology as follows; performance expectancy, effort expectancy, social influence, and facilitating conditions. First, performance expectancy is the degree to which such technology is beneficial to consumers in performing certain activities. While Effort expectancy represents the degree of ease of use of the technology. Then, Social influence which is the extent to which important others to the consumer, believe the consumer should use a technology. Finally, facilitating conditions which refers to consumers' perceptions of the resources and support available to perform the technology, its acceptance and usage behavior (Brown and Venkatesh, 2005; Venkatesh et al., 2003). In addition to the four factor, age, gender and experience were considered moderating the relationship between the four constructs and behavioral intentions. Complementary to UTAUT, Hedonic motivation, price value, experience and habits were added to the four constructs to extend the model to UTAUT2 (Venkatesh et al., 2012). Hedonic motivation has been used in consumer behaviour research (Holbrook and Hirchman, 1982). Hedonic motivation was defined as fun or pleasure derived from using technology, also, hedonic motivation has been conceptualized as perceived enjoyment (Van der Heijden, 2004; Thong et al, 2006). Price value was also integrated and defined as the extent that benefits of using technology are greater or less than the cost of using it. Finally, experience and habit reflect on the opportunity to use a target technology and was typically operationalized as the passage of time (Venkatesh et al., 2003). Lastly, habit was interpreted as the instrumental behaviour resulted from learning (Linayem et al., 2004)

In this paper, researchers conducted exploratory research on Mobile commerce consumers and experts to emphasise the variables that would enhance Mobile shopping users' adoption. They explored dependent and independent variables hypothesized in TAM and UTUAT2 models. The result emphasised 
the importance of perceived usefulness and ease of use as determinants of mobile commerce usage in Egypt. Furthermore, convenience, hedonic motivations, and social influence have a crucial effect on Mobile commerce, as of preliminary research.

\section{Perceived usefulness and Ease of use (EOU_PU)}

Perceived usefulness is the value addition of conducting any task using information technology or computing system, while perceived ease of use is the minimization of effort and time while using computing technology. Relative advantage and compatibility are the components of perceived usefulness. Relative advantages include several factors, such as cognitive and decisional control, enhanced privacy, improved security, and information access. Compatibility is matching of individual usage and lifestyles and the ability of the system to fulfil personal situational needs (Keeling 1999). Perceived usefulness is essential for anticipating buying intentions while perceived ease of use comes preceding usefulness (Igbaria, Guimaraes, \& Davis, 1995). The importance of such variables is determined by the characteristics of technology used (Gefen and Straub, 2000). Also, ease of use importance varied in a study on MBA students. Ease of Use was important in their usage of booksellers of e-books, however, it wasn't that important in the purchases. Moreover, there is empirical support provided for the relationship between usefulness and attitudes by several studies. There are many studies that tested the effect of perceived ease of use on Perceived usefulness. Some studies realized that the more the technology is easily used by users, the higher is its usefulness. Hence there is a direct effect of PEOU on usefulness. Also, there is an indirect positive effect of Perceived ease of use on attitudes through perceived usefulness (Davis, 1986, 1989). However, recently, in a study on online shopping in Korea (Wang, 2011), PU shows lower importance in affecting attitudes, while PEOU is getting to be a determinable requirement. In, Wu and Ke (2015) metaanalysis, PEOU had a direct effect on online shopping intentions without any mediation. On the other contrary, in a study conducted in Jordan (Faqih, 2011), PEOU tend to affect online purchasing intentions indirectly through perceived usefulness. Finally, in a study conducted in India on urban citizens' online shopping intentions, PEOU did have more of a direct effect on online shopping intentions than PU (Sirinvasan, 2015). Researchers concluded from literature that PEOU affect PU. Also, the importance of both variables varies depending on technology, usage and other variables included in different studies.

\section{Hedonic motivations (HM)}

Hedonic motivation is the pleasure or enjoyment resulting from technology adoption (Brown \& Venkatesh, 2005). HM affects behavioral intentions (Liao and Lin, 2007; Taylor and Venkatesh, 2010). However, it differs across stages of technology adoption. There are six dimensions of HM (Arnold \& Reynolds, 2003), adventure, social, gratification, idea, role, value and other hedonic dimensions such as pleasure, arousal and escapism (Perea, Monsuwé, Dellaert, \& De Ruyter., 2004). In another context, it represents the extent to which the technology is considered entertaining (Venkatesh et al., 2012). Initially, Information systems were designed as task oriented, the focus of adoption was on utilitarian factors such as PU and PEOU (Thong et al., 2006) but this concept changed to include an entertaining value, where it became more entertaining and enjoyable (Dwivedi et al., 2015).

Perceived enjoyment can be considered as a main component of hedonic motivation. Also, it is used interchangeably. In the current research, hedonic motivations are operationalized as perceived enjoyment. Enjoyment is an antecedent of PEOU \& PU, since an enjoyable technology is perceived easier and more useful than a monotonous one (Agrwal \& Kharahanna, 2000; van der Heijjden, 2004; Conci et al., 2009). Similarly, a study was conducted on first line managers of mid-sized companies on their usage of computers, confirmed that enjoyment affect both PU and PEOU (Fagan et al., 2008). Further, perceived enjoyment is fully mediated by PU and PEOU and it has no direct effect on behavioral intentions in the presence of PU and PEOU (Venkatesh et al., 2002; Zhang et al. 2003).

H1: Hedonic motivation has a positive significant relationship on perceived usefulness

H2: Hedonic motivation has a positive significant relationship on perceived ease of use

\section{Convenience (CONV)}

Convenience can be described as of a product or a service. A technology can be considered when it saves time, and saves cognitive, emotional and physical burden on users (Berry et al., 2002). There are three dimensions of convenience as described by Yoon \& Kim (2007): time, place and execution. Thus, 
convenience refers to the performance of a task at any time, in any place and in a burdenless manner. Convenience feature of Smart Phones is evident as individuals are not tied to immobile workstations, such as desktops at a home office which results in convenience in terms of performing daily routines while waiting for any official duties or taskes. With a free software download, the consumer has become highly independent on smart phones to retrieve the information by a single touch and click to access the smart phone as it is with them wherever they go (Islam et al., 2010; Genova, 2010). Shopping online is convenient as it provides the opportunity to shop 24 hours a day (Hofacker, 2001). Interactive shopping reduces the costs of acquiring information pre-purchase while increasing search benefits by providing a broader collection of product alternatives at a minimum cost (Bakos, 1991).

As concluded by Yoon \& Kim (2007), PEOU is one of the antecedents of perceived convenience, while convenience is one of the antecedents of PU. Similarly, this is true for e-learning systems using mobile learning (Gwebu \& Wang, 2011). Further, on the E-learning system MOODLE, the TAM Model was extended by perceived convenience (Hsu \& Chang, 2013). Confirmed by the previously discussed literature, convenience was an antecedent for Perceived Usefulness and affected by PEOU. As of Childers et, al., (2001), convenience has a positive effect on PE and PEOU.

H3: convenience has a positive significant effect on perceived usefulness.

H4: convenience has a positive significant effect on perceived ease of use.

In a study conducted on information searches habits of tourists using mobile technologies, the quality of ubtiquous tourist information has four dimensions, interface design, system quality, convenience and system quality. Those four dimensions were tested on perceived enjoyment and mobile usage. Convenience didn't have a significant impact on enjoyment (Kim et al., 2012). However, in another study on online shopping, there was a significant relationship between convenience and enjoyment (Childers et al., 2001).

\section{H5: Convenience has a positive significant direct effect on hedonic motivation}

\section{Social influence (SI)}

Social influence is defined as "the degree to which an individual perceives that other important persons believe he or she should use the system" (Kripanont, 2007). Moreover, it refers to the way other people affect a person's beliefs, feeling and values (Foon et al., 2011: Jaganathana et al., 2014). Also, it is the degree to which significant people to the user perceive that technology is crucial to him (Diaz \& Loraas, 2010). It is similar to the factor "subjective norm" as defined in the extension of Technology Acceptance Model (TAM2). Subjective norm contains the explicit or implicit concept that the technology users are influenced by the way they believe others will view them concerning technology usage (Chang 2012). Subjective norms are used interchangeably with SI and it is tested in the theory of technology acceptance and theory of planned behavior. Further, social influence is a significant factor in predicting technology and usage behavior as we consider others perception of what we should do or want us to do in adopting any innovation (Fishbein \& Ajzen, 1975). Furthermore, it is the influence of an individual social environment on his or her behavioral intentions (Zhang et al., 2012).

SI has a positive direct relationship with PEOU and PU as confirmed by literature (Farahat, 2012; Wolfson, Magnoum, and Marsom, 2007; Park 2009 \& Ramayah et, al., 2005). Similarly, subjective norms had a significant effect on perceived usefulness and behavioral intentions (Venkatesh and Davis, 2000). Also, there is a significant direct relationship between subjective norms and PU but an indirect relationship with behavioral intentions (Rose and Fogarty, 2006). However, in another study, there was a direct relationship between subjective norms and behavioral intentions (Scheper \& Wetzels, 2007).

Regarding the relationship between social influence or subjective norms and Perceived enjoyment or hedonic motivations, Park et al, (2011) studied the behavior of mobile communication users on 3G services and found that SI had a significant relationship on both PU and perceived enjoyment; however, it has a higher influence on perceived enjoyment. Thus, researchers focused on the importance of considering the effect of relatives and friends in designing marketing campaigns. Consequently, in mobile payments adoption, social influence has shown to affect user's behavior in adoption of mobile phone services (Kim et a. 2007) mobile internet (Kim, Chan And Gupta, 2007) and online game communication 
(Hsu \& Lu, 2007). It is evident that perceived enjoyment is a socially constructed phenomenon as many hedonic products are consumed in presence of others. So, mobile payments tend to affect positively perceived enjoyment and PU (Lewis et al, 2015; Venkatesh et al., 2012)

Thus, the following hypotheses were drawn from the above literature, H6: Social influence has a positive significant direct effect on Perceived usefulness.

H7: Social influence has a positive significant direct effect on Perceived ease of use.

H8: Social influence has a positive significant direct effect on hedonic motivations.

\section{Method}

This study aimed to collect data across Smartphone owners who conduct mobile shopping to test the proposed research model and its corresponding hypotheses. The survey items used to measure the constructs were extracted from literature. There are 5 variables in this questionnaire; PEOU, PU, CONV, HM and SI. The convenience scale was developed by Chang et al., (2012), while other variables HM and SI were extracted from the scales developed by Vanketesh et al, (2012) when developing his extension for the UTAUT2 model. Finally, the two independent variables, PEOU and PU were extracted from the original TAM model. Each questionnaire item used a 5-point Likert-type scale that ranged from 1 (strongly disagree) to 5 (strongly agree). The questionnaire was translated into Arabic, so there was a version in English and another version in Arabic. Potential respondents were randomly approached for convenience. This method was used because the population of mobile shoppers in Egypt is quite limited. The researchers checked to determine whether the potential respondents were appropriate for this study. They were asked whether they had participated in this survey before and whether they conducted mobile shopping in Egypt. After fulfilling these criteria, the respondent was given a questionnaire for completion.

A two-step approach involving structural equation modeling (SEM) was adopted for measurement scale validation and structural analysis (Byrne, 2000; Hair et al., 2010). The maximum likelihood estimation procedure was employed using AMOS Version 20. This study's proposed research model was analyzed following three main steps. First, a covariance matrix of all measured variables was constructed and subjected to a series of validity and reliability checks. Upon establishing the model fit, we estimated the significance and size of each structural parameter for the specified model. The detailed results of the analysis are discussed below.

\section{Descriptive analysis}

The questionnaire was administrated only to persons who had smart phones. The respondent included almost as many as males as females and included a broad range of all levels. The percentages of respondents are shown in table (1),

\begin{tabular}{|c|c|c|}
\hline \multicolumn{3}{|c|}{ Table 1: Demographics } \\
\hline Characteristics & Frequency & Percentage \\
\hline Gender: & & \\
\hline 1. Male & 93 & $46.5 \%$ \\
\hline 2. Female & 107 & $53.5 \%$ \\
\hline Age: & & \\
\hline 1. Less than 25 & 96 & $48 \%$ \\
\hline 2. 25 to less than 30 years old & 35 & $17.5 \%$ \\
\hline 3. 30 less than 40 years old & 31 & $15.5 \%$ \\
\hline 4. 40 less than 50 years old & 27 & $13.5 \%$ \\
\hline 5. 50 less than 60 & 10 & $5.0 \%$ \\
\hline 6. 60 or older & 1 & $0.5 \%$ \\
\hline Education: & & \\
\hline 1. Uneducated & 0 & $0 \%$ \\
\hline 2. Primary or preparatory & 0 & $0 \%$ \\
\hline 3. High school graduate & 71 & $35.5 \%$ \\
\hline 4. Graduate (Bachelor degree) & 98 & $49 \%$ \\
\hline 5. Post graduate & 31 & $15.5 \%$ \\
\hline
\end{tabular}




\section{Data analysis}

\section{Reliability and Validity of Measurement Items}

A confirmatory factor analysis (CFA) of all items was simultaneously conducted to evaluate the validity of the items and the eight underlying constructs in the measurement model. Table 2 summarizes the results of the measurement model across the model-fit indices. All model-fit indices indicate that the measurement model exhibits a good fit with the data collected. Hence, we proceeded to examine the measurement model's psychometric properties to evaluate its reliability and construct validity. Construct validity was examined using the test for convergent and discriminant validity. Convergent validity was evaluated using the attributes of factor loading, average variance extracted (AVE), and construct reliability (CR). Table 3 shows the factor loading, AVE, and CR values that were used to assess convergent validity for the CFA model.

\begin{tabular}{|l|r|}
\hline \multicolumn{2}{|c|}{ Table 2: Measurement for goodness of Fit for CFA model } \\
\hline \multicolumn{2}{|c|}{ Goodness of Fit measure } \\
\hline Chi-Square Value $\left(X^{2}\right)$ & 171.294 \\
\hline P value & 0.001 \\
\hline DF & 80 \\
\hline X2/DF & 2.1 \\
\hline AGFI & .860 \\
\hline GFI & .907 \\
\hline CFI & .927 \\
\hline NFI & .874 \\
\hline RMSEA & .076 \\
\hline
\end{tabular}

Note. GFI = goodness-of-fit index; AGFI = adjusted goodness-of-fit index; CFI = comparative fit index; $\mathrm{NFI}=$ normed fit index; RMSEA = root mean square error of approximation.

\begin{tabular}{|c|c|c|c|c|}
\hline Factor & Item & Standardized factor loading & AVE & CR \\
\hline \multirow[b]{4}{*}{ CONV } & CONV_1 & $\begin{array}{ll} & .803\end{array}$ & \multirow[b]{4}{*}{0.69} & \multirow[b]{4}{*}{0.779} \\
\hline & CONV_2 & .845 & & \\
\hline & CONV_3 & .771 & & \\
\hline & CONV_4 & .689 & & \\
\hline \multirow[b]{3}{*}{$\mathrm{HM}$} & HM_1 & .810 & \multirow[b]{3}{*}{0.813} & \multirow[b]{3}{*}{0.835} \\
\hline & HM_2 & .870 & & \\
\hline & HM_3 & .834 & & \\
\hline \multirow[b]{2}{*}{ SI } & SI_1 & .899 & \multirow[b]{2}{*}{0.853} & \multirow[b]{2}{*}{0.842} \\
\hline & SI_2 & .939 & & \\
\hline \multirow[b]{6}{*}{ EOU and PU } & EOU_1 & .654 & \multirow[b]{6}{*}{.679} & \multirow[b]{6}{*}{0.835} \\
\hline & EOU_5 & .911 & & \\
\hline & EOU_6 & .778 & & \\
\hline & PU_4 & .537 & & \\
\hline & PU_5 & .774 & & \\
\hline & PU_6 & .619 & & \\
\hline
\end{tabular}

Note: $\mathrm{AVE}$ = average variance extracted; $\mathrm{CFA}$ = confirmatory factor analysis; $\mathrm{CR}$ = construct reliability; COV: convenience; HM: hedonic motivation; SI: social influence; PU: Perceived usefulness; EOU: perceived ease of use

www.jbrmr.com A Journal of the Academy of Business and Retail Management (ABRM) 


\begin{tabular}{|l|r|l|l|l|}
\hline \multicolumn{7}{|c|}{ Table 4: The AVE and Squared Correlation Estimates } \\
\hline & HM & EOU_PU & CONV & SI \\
\hline HM & $\mathbf{0 . 8 1 3}$ & & & \\
\hline EOU_PU & 0.502 & $\mathbf{0 . 6 7 9}$ & & \\
\hline CONV & 0.427 & 0.567 & $\mathbf{0 . 6 9}$ & $\mathbf{0 . 8 5 3}$ \\
\hline SI & 0.442 & 0.347 & 0.16 & \\
\hline
\end{tabular}

All scale items are highly loaded on their respective constructs, as all factor loadings are above the threshold value of 0.70 except for one dimension (table3). Each indicator's item reliability, including CR, was above .70, suggesting good reliability and convergent validity (table 3 ). Notably, all CR values for the constructs in the model were above .7, which provides strong evidence that these measures consistently represent the same latent construct. The AVE values were compared with the squared estimate of the correlation estimates to assess discriminant validity. The correlation matrix in Table 4 shows that all AVE values are greater than the squared correlation estimates; this result confirms that a satisfactory level of discriminant validity has been achieved and indicates that the measured variables have more in common with the construct with which they are associated than with other constructs in the model. Furthermore, this finding indicates that all constructs in the measurement model are significantly different from one another.

\section{Structural Model and Hypothesis Testing}

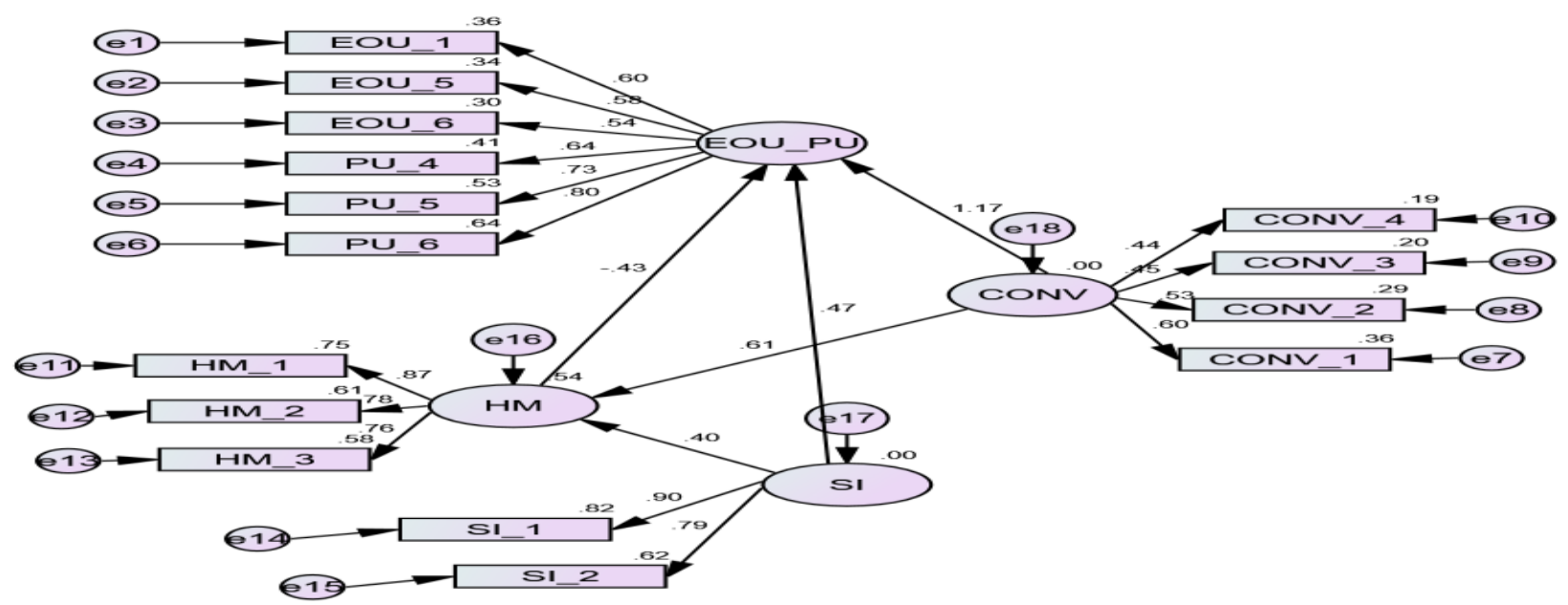

Figure 1: Path analysis

The results of the full structural model showed a good fit of the data to the model: $\chi 2 / \mathrm{df}=1.865$, goodness-of-fit index $(\mathrm{GFI})=0.923$, adjusted goodness-of-fit index (AGFI) $=0.878$, comparative fit index $(\mathrm{CFI})=0.947$, normed fit index $(\mathrm{NFI})=0.895$, standardized root mean square residual $(\mathrm{SRMR})=0.038$, and root mean square error of approximation (RMSEA) $=0.066$. This study tested each hypothesis by examining the path significance. Figure 2 illustrates the path diagram with the resulting fully standardized structural parameter estimates included on the paths. The paths from CONV, HM, and SI to Perceived usefulness and perceived ease of use as they are collected in one factor, are statistically significant in the current user group (as all $\mathrm{p}$-values is less than 0.05). These factors explained $50.7 \%$ of the variance.

\section{Discussion}

As of exploratory factor analysis conducted, perceived ease of use and perceived usefulness did merge into one factor in this research. One possible explanation, that most of the respondents perceived them similarly. 
On considering the effect of other variables such as hedonic motivations, social influence and convenience, there is a direct positive relationship between all variables and Perceived ease of use and perceived usefulness. As follows, the standardized estimates are $.983, .261 \& .231$ with no mediations. As is evident, Convenience has the strongest effect on perceived usefulness and ease of use. However, on exploring the paths between convenience and Hedonic motivation on one hand and social influence on hedonic motivation on the other, the relationship between Hedonic motivation and perceived ease of use and perceived usefulness became a negative relationship. To better identify the reasons for such change in the relationship, the mediation effect for convenience was tested. Also, the mediation effect for Hedonic motivation was tested for the relationship between social influence and Perceived ease of use and usefulness.

\begin{tabular}{|l|lr|r|l|}
\hline \multicolumn{5}{|c|}{ Table 5: Hypothesis testing } \\
\hline Paths & Standardized estimates & \multicolumn{1}{l|}{ P-value } & Hypothesis supported \\
\hline CONV $\rightarrow$ EOU-PU & 1.114 & 0.001 & H1 \&2 Supported \\
\hline HM $\rightarrow$ EOU-PU & -0.43 & 0.041 & H3 \&H4 supported \\
\hline $\mathrm{SI} \rightarrow$ EOU-PU & 0.457 & 0.001 & H6 \& H7 supported \\
\hline $\mathrm{SI} \rightarrow \mathrm{HM}$ & 0.426 & 0.001 & H8 supported \\
\hline $\mathrm{CONV} \rightarrow \mathrm{HM}$ & 0.571 & 0.001 & H5 supported \\
\hline
\end{tabular}

As table 6 shows, there is indirect effect of social influence on perceived usefulness and ease of Through Hedonic motivations and convenience. On testing the mediation effect of convenience, social influence was fully mediated by convenience as the direct effect of social influence on PU_EOU became completely insignificant. As a result, convenience was considered as a strong mediator on the relationship between SI and PU_EOU.

On the other hand, in exploring the mediating effect of hedonic motivation, hedonic motivation didn't mediate the relationship between SI and PU_EOU. The indirect effect of hedonic motivation is considered insignificant.

However, when hedonic motivation \& convenience are considered together, they are fully mediating the relationship between social influence and perceived usefulness and ease of use.

\begin{tabular}{|l|c|c|c|}
\hline \multicolumn{5}{|c|}{ Table 6: Mediation analysis } \\
\hline SI-CONV-EOU_PU & Total effect & Direct effect & Indirect effect \\
\hline SI-HM-EOU_PU & $0.390(.014)$ & $0.147(.484)$ & $0 . .181(.108)$ \\
\hline SI-HM-CONV-EOU_PU & $0.300(.032)$ & $0.236(0.088)$ & $0.064(.338)$ \\
\hline SI-HM-CONV-EOU_PU & $0.409(0.02)$ & $.113(0.669)$ & $.296(.098)$ \\
\hline
\end{tabular}




\section{Conclusion, implications and limitations}

Figure 2: path analysis after mediation effect

As it is evident from the discussion, that social influence, hedonic motivations and convenience are significant factors for enhancing the usefulness and ease of use of mobile commerce in Egypt. However, convenience tends to affect the usefulness and ease of use the most. Also, social influence could be fully mediated if the users found more convenience either in terms of time or effort for the usage of mobile commerce. Mobile commerce user would consider it useful even though social influence is not in line with. In literature, social influence did have an influence however, with this new conclusion, marketers would focus more on developing more excitement and pleasure and convenience rather than focusing on other people's opinion in mobile commerce. For future research, the complete model including the adoption and usage of technology would be of benefit if compared for different age groups and in different countries in Arab world region. This research was conducted in Cairo only and it didn't consider other governates, as most of the smart device users live in Cairo governates, as Cairo has the largest population and highest incomes among Egypt governates (El-Tawila, Gadalla and Einas Ali, 2013). Also, the age groups are mostly teenagers and young adults, as most of smart users are younger generations less than 40 years old (Alex bank research, 2015).

\section{References}

Agarwal, R., \& Karahanna, E. (2000). Time flies when you're having fun: Cognitive absorption and beliefs about information technology usage. MIS quarterly, 665-694.

Ajzen, I. (1988). Attitudes, Personality and Behavior.

Ajzen, I. (1991). The theory of planned behavior. Organizational behavior and human decision processes, 50(2), $179-211$.

Ajzen, I. (2002). Perceived behavioral control, Self-Efficacy, locus of control, and the theory of planned Behavior1. Journal of applied social psychology, 32(4), 665-683.

Alex bank research team, (2015), Egypt digital economy 2015. Alexandria bank, Egypt,

https://www.alexbank.com/Cms_Data/Contents/AlexBank_En/Media/Publication/Egypts_Digital_Ec onomy_2015_English-pd.pdf

Bagozzi, R. P., Davis, F. D., \& Warshaw, P. R. (1992). Development and test of a theory of technological learning and usage. Human relations, 45(7), 659-686.

Bakos, J. Y. (1991). A strategic analysis of electronic marketplaces. MIS quarterly, 295-310.

Berry, L. L., Seiders, K., \& Grewal, D. (2002). Understanding service convenience. Journal of marketing, 66(3), 1-17.

Berry, L. L., Seiders, K., \& Grewal, D. (2002). Understanding service convenience. Journal of Marketing Research, 66, 1-17.

Brown, S. A., \& Venkatesh, V. (2005). Model of adoption of technology in households: A baseline model test and extension incorporating household life cycle. MIS quarterly, 399-426.

Byrne, B. M. (2013). Structural equation modeling with Mplus: Basic concepts, applications, and programming. Routledge.

Chang, C. C., Yan, C. F., \& Tseng, J. S. (2012). Perceived convenience in an extended technology acceptance model: Mobile technology and English learning for college students. Australasian Journal of Educational Technology, 28(5).

Childers, T. L., Carr, C. L., Peck, J., \& Carson, S. (2001). Hedonic and utilitarian motivations for online retail shopping behavior. Journal of Retailing, 77(4), 511-535. doi:10.1016/ s0022-4359(01)00056-2

Conci, M., Pianesi, F., \& Zancanaro, M. (2009). Useful, social and enjoyable: Mobile phone adoption by older people. Human-computer interaction-INTERACT 2009, 63-76.

Courneya, K. S., \& Friedenreich, C. M. (1999). Utility of the theory of planned behavior for understanding exercise during breast cancer treatment. Psycho-oncology, 8(2), 112-122.

Davis, F. D. (1985). A technology acceptance model for empirically testing new end-user information systems: Theory and results (Doctoral dissertation, Massachusetts Institute of Technology).

Davis, F. D. (1989). Perceived Usefulness, Perceived Ease of Use, and User Acceptance of Information Technology. MIS Quarterly, 13(3), 319. doi:10.2307/249008 
Davis, F. D., Bagozzi, R. P., \& Warshaw, P. R. (1989). User Acceptance of Computer Technology: A Comparison of Two Theoretical Models. Management Science, 35(8), 982-1003.

doi:10.1287/mnsc.35.8.982

Diaz, M. C., \& Loraas, T. (2010). Learning new uses of technology while on an audit engagement: Contextualizing general models to advance pragmatic understanding. International Journal of Accounting Information Systems, 11(1), 61-77.

Dwivedi, Y. K., Wastell, D., Laumer, S., Henriksen, H. Z., Myers, M. D., Bunker, D., ... \& Srivastava, S. C. (2015). Research on information systems failures and successes: Status update and future directions. Information Systems Frontiers, 17(1), 143-157.

El-Tawila, S., May Gadalla and Einas Ali (2013). "Income Poverty and Inequality in Egypt's Poorest Villages". The World Bank and Social Contract Center, Experts' Group Meeting, May 27th, Cairo, Egypt.

Faqih, K. M. (2011). Integrating perceived risk and trust with technology acceptance model: An empirical assessment of customers' acceptance of online shopping in Jordan. 2011 International Conference on Research and Innovation in Information Systems. doi:10.1109/icriis.2011.6125686

Farahat, T. (2012). Applying the Technology Acceptance Model to Online Learning in the Egyptian Universities. Procedia - Social and Behavioral Sciences, 64, 95-104. doi: 10.1016/j.sbspro.2012.11.012

Fishbein, M., \& Ajzen, I. (1975). Belief, attitude, intention, and behavior: An introduction to theory and research. Reading, MA: Addison-Wesley Pub.

Foon, Y. S., \& Fah, B. C. Y. (2011). Internet banking adoption in Kuala Lumpur: an application of UTAUT model. International Journal of Business and Management, 6(4), 161-167.

Gefen, D., \& Straub, J. W. (2000, October). The relative importance of perceived ease of use in IS adoption: A study of e-commerce adoption, Journal of the Association of Information System, 1. Retrieved from http:/ /jais.isworld.org/articles/ default.asp?vol1/41\&art $1 / 48$

Gwebu, K. L., \& Wang, J. (2011). Adoption of Open Source Software: The role of social identification. Decision Support Systems, 51(1), 220-229.

Hair, J. F., Anderson, R. E., Babin, B. J., \& Black, W. C. (2010). Multivariate data analysis: A global perspective (Vol. 7). Upper Saddle River, NJ: Pearson.

Hofacker, C.F., (2001), Internet Marketing (3rd ed.), John Wiley \& Sons, Inc, New York.

Hohenberg, H. E., \& Rufera, S. (2004). Das Mobiltelefon als Geldbörse der Zukunft-Chancen und Potentiale des Mobile Payment (M-Payment). der markt, 43(1), 33-40.

Holbrook, M. B., \& Hirschman, E. C. (1982). The experiential aspects of consumption: Consumer fantasies, feelings, and fun. Journal of consumer research, 9(2), 132-140.

Hsu, C. L., \& Lu, H. P. (2007). Consumer behavior in online game communities: A motivational factor perspective. Computers in Human Behavior, 23(3), 1642-1659.

Hsu, H. H., \& Chang, Y. Y. (2013). Extended TAM model: Impacts of convenience on acceptance and use of Moodle. Online Submission, 3(4), 211-218.

Igbaria, M., Guimaraes, T., \& Davis, G. B. (1995). Testing the determinants of microcomputer usage via a structural equation model. Journal of management information systems, 11(4), 87-114.

Islam, M. A., Ahmad, T. S. B., Khan, M. A., \& Ali, M. H. (2010). Adoption of M-commerce services: The case of Bangladesh. World Journal of Management, 2(1), 37-54.

Jaganathan, M., Mustapa, A. N., Hasan, W. A. W., Mat, N. K. N., \& Alekam, J. M. E. (2014, December). Does dependency make a difference? The role of convenience, social influence, facilitating condition and self-efficacy on student's purchase behaviour of smartphone. In H. Ibrahim, J. Zulkepli, N. Aziz, N. Ahmad, \& S. A. Rahman (Eds.), AIP Conference Proceedings (Vol. 1635, No. 1, pp. 332-339). AIP.

Keeling, M. (1999). Spatial models of interacting populations (pp. 64-99). Blackwell Science, Oxford, UK.

Kim, C., Galliers, R. D., Shin, N., Ryoo, J. H., \& Kim, J. (2012). Factors influencing Internet shopping value and customer repurchase intention. Electronic Commerce Research and Applications, 11(4), 374-387.

Kim, H. W., Chan, H. C., \& Gupta, S. (2007). Value-based adoption of mobile internet: an empirical investigation. Decision support systems, 43(1), 111-126. 
Kim, J., Fiore, A. M., \& Lee, H. H. (2007). Influences of online store perception, shopping enjoyment, and shopping involvement on consumer patronage behavior towards an online retailer. Journal of retailing and Consumer Services, 14(2), 95-107.

KIT, A. K. L. (2014). UTAUT2 influencing the behavioural intention to adopt mobile applications (Doctoral dissertation, UNIVERSITI TUNKU ABDUL RAHMAN).

Koenig-Lewis, N., Marquet, M., Palmer, A., \& Zhao, A. L. (2015). Enjoyment and social influence: predicting mobile payment adoption. The Service Industries Journal, 35(10), 537-554.

Koenig-Lewis, N., Marquet, M., Palmer, A., \& Zhao, A. L. (2015). Enjoyment and social influence: predicting mobile payment adoption. The Service Industries Journal, 35(10), 537-554.

Kripanont, N. (2007). Examining a technology acceptance model of internet usage by academics within Thai business schools (Doctoral dissertation, Victoria University).

Lee, M. C. (2009). Factors influencing the adoption of internet banking: An integration of TAM and TPB with perceived risk and perceived benefit. Electronic commerce research and applications, 8(3), 130-141.

Limayem, M., Khalifa, M., \& Chin, W. W. (2004). Factors motivating software piracy: a longitudinal study. IEEE transactions on engineering management, 51(4), 414-425.

Magni, M., Taylor, M. S., \& Venkatesh, V. (2010). 'To play or not to play': A cross-temporal investigation using hedonic and instrumental perspectives to explain user intentions to explore a technology. International journal of human-computer studies, 68(9), 572-588.

Mayer, R. C., Davis, J. H., \& Schoorman, F. D. (1995). An integrative model of organizational trust. Academy of management review, 20(3), 709-734.

Morosan, C., \& DeFranco, A. (2016). It's about time: Revisiting UTAUT2 to examine consumers' intentions to use NFC mobile payments in hotels. International Journal of Hospitality Management, 53, 17-29.

Müller-Veerse, F. (2001), Umts Report - an Investment Perspective, Durlacher

Park, N., Jung, Y., \& Lee, K. M. (2011). Intention to upload video content on the internet: The role of social norms and ego-involvement. Computers in Human Behavior, 27(5), 1996-2004.

Park, N., Kee, K. F., \& Valenzuela, S. (2009). Being immersed in social networking environment: Facebook groups, uses and gratifications, and social outcomes. CyberPsychology \& Behavior, 12(6), 729-733.

Park, S. Y. (2009). An analysis of the technology acceptance model in understanding university students' behavioral intention to use e-learning. Educational technology \& society, 12(3), 150-162.

Payfort's Middle East State of Payment Report, (2014). [Online]. Available from: http://digioh. com/emd/1362679/sjei70h29k. Retrieved on February 13 th

Perea y Monsuwé, T., Dellaert, B. G., \& De Ruyter, K. (2004). What drives consumers to shop online? A literature reviews. International journal of service industry management, 15(1), 102-121.

Pricewaterhouse Coopers (PWC) "Total retail survey." 2015.

https://www.pwc.com/gx/en/industries/retail-consumer/total-retail.html 0(Accessed: March 5, 2015).

Ramayah, T., \& Ignatius, J. (2005). Impact of perceived usefulness, perceived ease of use and perceived enjoyment on intention to shop online. ICFAI Journal of Systems Management (IJSM), 3(3), 36-51.

Rhodes, R. E., \& Courneya, K. S. (2003). Relationships between personality, an extended theory of planned behaviour model and exercise behaviour. British Journal of Health Psychology, 8(1), 19-36.

Rose, J., \& Fogarty, G. (2006). Determinants of perceived usefulness and perceived ease of use in the technology acceptance model: senior consumers' adoption of self-service banking technologies. Academy of World Business, Marketing \& Management Development, 2(10), 122-129.

Sara Aggour, "Egyptian e-commerce market to reach $\$ 2.7$ bn by 2020," Daily News Egypt, May 12, 2015, www.dailynewsegypt.com/2015/05/12/egyptian-e-commerce-market-to-reach-2-7bn-by-202/

Schepers, J., \& Wetzels, M. (2007). A meta-analysis of the technology acceptance model: Investigating subjective norm and moderation effects. Information $\mathcal{E}$ management, 44(1), 90-103.

Srinivasan, R. (2015). Exploring the Impact of Social Norms and Online Shopping Anxiety in the Adoption of Online Apparel Shopping by Indian Consumers. Journal of Internet Commerce, 14(2), 177-199. doi:10.1080/15332861.2015.1008891

Thong, J. Y., Hong, S. J., \& Tam, K. Y. (2006). The effects of post-adoption beliefs on the expectationconfirmation model for information technology continuance. International Journal of HumanComputer Studies, 64(9), 799-810. 
To, P. L., Liao, C., \& Lin, T. H. (2007). Shopping motivations on Internet: A study based on utilitarian and hedonic value. Technovation, 27(12), 774-787

UNCTAD (2002), World Investment Report 2002: Transnational Corporations and Export Competitiveness. Geneva: United Nations

Van der Heijden, H. (2004). User acceptance of hedonic information systems. MIS quarterly, 695-704.

Venkatesh, V., \& Davis, F. D. (2000). A theoretical extension of the technology acceptance model: Four longitudinal field studies. Management science, 46(2), 186-204.

Venkatesh, V., Morris, M. G., Davis, G. B., \& Davis, F. D. (2003). User acceptance of information technology: Toward a unified view. MIS quarterly, 425-478.

Venkatesh, V., Speier, C., \& Morris, M. G. (2002). User acceptance enablers in individual decision making about technology: Toward an integrated model. Decision sciences, 33(2), 297-316.

Venkatesh, V., Thong, J. Y., \& Xu, X. (2012). Consumer acceptance and use of information technology: extending the unified theory of acceptance and use of technology.

Wang, Y. C. (2016, July). Exploring the Causes of Smartphone Dependency and Purchasing Behavior. In Advanced Applied Informatics (IIAI-AAI), 2016 5th IIAI International Congress on (pp. 745-748). IEEE.

Wolfson, G. K., Magnuson, C. W. and Marsom, G. (2005). Changing the nature of the discourse: Teaching field seminars online. Journal of Social Work Education, 41, 355-361.

Wu, W., \& Ke, C. (2016). An Online Shopping Behavior Model Integrating Personality Traits, Perceived Risk, and Technology Acceptance. Social Behavior and Personality: An International Journal Soc Behav Personal, 44(3), 85-97. doi:10.2224/sbp.2015.43.1.85

Yoon, C., \& Kim, S. (2007). Convenience and TAM in a ubiquitous computing environment: The case of wireless LAN. Electronic Commerce Research and Applications, 6(1), 102-112.

Zhang, Y., Lee, W., \& Huang, Y. A. (2003). Intrusion detection techniques for mobile wireless networks. Wireless Networks, 9(5), 545-556. 